\title{
THE FIRST DIRECTLY DATED CAVE BEAR FROM THE COVOLI DI VELO CAVE (VERONA PROVINCE, VENETO, NORTHERN ITALY) WITH SOME DISCUSSION OF ITALIAN ALPS CAVE BEARS
}

\author{
Mario Rossi ${ }^{1}$, Giuseppe Santi ${ }^{2}$ c, Roberto Zorzin ${ }^{5}$, Doris Döppes ${ }^{3}$, Ronny Friedrich ${ }^{4}$, Susanne \\ Lindauer $^{4}$, and Wilfried Rosendahl ${ }^{3}$
}

\section{Abstract}

Absolute dates of cave bears from Northern Italy are rare. The first radiocarbon date from Covoli di Velo Cave (Verona Province, Veneto, N. Italy) from a cave bear first phalanx is reported; its value is $29,130 \pm 0.90{ }^{14} \mathrm{C}$ yr BP. The date, combined with morphological features of dentition suggest that cave bear populations that lived in Northern Italy were relatively underived compared to other European populations, hinting at patters of migration. Comparison of dental morphology suggest that the Covoli di Velo bear is Ursus spelaeus.

\section{Introduction}

In recent years, knowledge of the paleobiology of the cave bear (Ursus spelaeus Rosenmüller, 1794) has greatly expanded. This is a consequence of numerous studies on the morphometry (historically the most common study) on the morphodynamics of the dentition (i.e. Torres, 1988 a-f; Withalm, 2001; Rabeder, 1999, 2014; Grandal d'Anglade and López-González, 2004; Sabol, 2005; Tsoukala et al., 2006; Baryshnikov and Puzachenko, 2011; 2017; Cvetković and Dimitrijević, 2014; Frischauf, 2014; Robu, 2016; Plichta et al., 2017), absolute dating, as well as genetics (Hofreiter et al., 2002; Orlando et al., 2002; Rabeder et al., 2004; Pacher and Stuart, 2008; Spötl et al., 2014, 2017; Martini et al., 2014; Döppes et al., 2016, 2018; Baca et al., 2016, 2017; Fortes et al., 2017; Gretzinger et al., 2017; Terlato et al., 2018 and so on). The most important results of this knowledge have been to modify the phylogenetic tree of the cave bear. In fact, when considering overall the genetic data, different species of cave bears have been identified (Ursus ingressus, $U$. spelaeus eremus and U. spelaeus ladinicus) (Rabeder et al., 2004) with their distribution throughout Europe (Doppes et al, 2018). In Italy, morphometric and morphodynamic studies are numerous (i.e. Santi and Rossi, 2001, 2014; Santi et al., 2003, 2011; De Carlis et al., 2005; Rabeder et al., 2004), but genetic studies and reports on absolute dating are very rare. With this in mind, the present study presents the results of the first absolute dating with ${ }^{14} \mathrm{C}$ (authorization MBACSBA-VEN 050015108 19/11/2014), performed on the first phalanx of $U$. spelaeus found in recent surveys coordinated by one of the Authors (R.Z.), in sector B L1/Z2 sup. 1 of the excavation in the Covoli di Velo Cave (Grotta inferiore) (Verona, Veneto) (cadastral number 44 V VR) (Fig. 1 A). The specimen (I.G.VR 63925) is stored in the Department of Geology and Paleontology, Civic Museum of Natural History of Verona (Veneto region, Northern Italy). This new information greatly improves the state of knowledge gathered in prior excavations (Bona et al., 2006).

\section{Covoli di Velo Cave: Research History}

Since the 18th Century, Covoli di Velo Cave has been the object of study by the most important noted naturalists of the Verona area. The first definite report of this site goes back to the late 1700's, when the Abbot Fortis, in a letter (24 September 1785) sent to the Count de Cassini, (Fortis, 1786) described and identified the bones from the cave as "amfibj" (amphibians). A few years later, Serafino Volta (1796) corrected Fortis, proposing that the bones belonged to continental animals. Later, Catullo (1844) visited the cave confirming the presence of a lot of bones, and Massalongo (1851) accurately described both the Covoli di Velo Cave geology and added to the collection of fossils from the site. With his precisely detailed description of the Covoli di Velo Cave, Massalongo proposed some hypotheses supported by tables and by beautiful illustrations, on the origin of both the cave and bones. Although some of the hypotheses were not accurate, the study by Massalongo is considered the first scientific study on the Covoli di Velo Cave.

Omboni (1875) published an important memoir about this cave in which he described and illustrated various paleontological remains. He pointed out the problem of the lack of research and of excavations using scientific methods, and that this created a risk of lost scientific knowledge about the history and taphonomy of the accumulated fossils. Omboni also mentioned the problem of illegal excavations, which went on for decades and ruined a significant amount of paleontological data. In fact, while some scientists gathered a paltry number of fossils, the locals (Benetti and Cristoferi, 1968; Benetti and Sauro, 1999) made profits by selling cave sediments as topsoil, and sold the bones, whole or

\footnotetext{
1Department of Geology and Paleontology, Civic Museum of Natural History, Lungadige Porta Vittoria 9, I-37129 Verona, Italy

${ }^{2}$ Department of Earth and Environmental Science, University of Pavia, Via Ferrata 1, I-27100 Pavia, Italy

${ }^{3}$ Reiss-Engelhorn-Museen, Zeughaus C5, 68159 Mannheim, Germany

${ }^{4}$ Curt-Engelhorn-Zentrum Archäometrie gGmbH, D6, 3, D-68159 Mannheim, Germany

${ }^{5}$ Geologist freelance, Verona, Italy

c Corresponding Author: gsanti@unipv.it
} 
crushed, as good fertilizer. For these reasons, the collection of bones was eventually prohibited. However, the illegal excavations by collectors and dealers, continued for many decades. In the first half of 20th Century, a few authors studied the Covoli di Velo Cave, but did not add scientific data (Fabiani, 1919).

In 1970, speleologists from the Centro Ricerche Idrologiche e Speleologiche Veronese (C.R.I.S.V.) discovered a new room (Benetti, 1973); that discovery confirmed that the explorations of the galleries with fossils was far from completed. Only in 2001 did the Ente Parco Naturale Regionale della Lessinia close the Grotta Inferiore, and the Museo Civico di Storia Naturale di Verona begin a series of paleontological excavations with the authorization of the Ministero dei Beni e delle Attività Culturali that continued until 2008.

\section{Stratigraphy of the Grotta Inferiore of Covoli di Velo Cave}

The karst system of Covoli di Velo Cave is located in one of the most interesting areas of the central-eastern part of the Lessini Mountains (Verona province-Veneto) because of its geology and paleontological content (Bon et al., 1991). The cave opens into the Valley of Covolo, a tributary of the deep Valley Illasi (Fig. 1A).

The karst system of the Covoli di Velo Cave is composed of three main chambers: Grotta superiore and Grotta inferiore or Grotta dell'orso (totalling $364 \mathrm{~m}$ long), the Covolo dell'Acqua (65 m long), and some minor tunnels. The cave principally has a sub-horizontal direction, with the mouth of the cave opening at about $870 \mathrm{~m}$ above sea level. The cave is formed in oolitic calcarenites, a local dolomitization of the Calcari Grigi di Noriglio Formation (Lower Jurassic).

In the cave, the connections between the passageways, are often limited and may be blocked by large alluvial and collapse deposits, that in various ways close the chambers (Zorzin and Rossi, 1999). The Grotta inferiore of the Covoli di Velo (cadastral number $44 \mathrm{~V}$ VR), preserves a great quantity of Ursus gr. spelaeus fossils. For this reason in October 2001, the Geology and Paleontology Section of the Civic Museum of Natural History of Verona (Zorzin and Bona, 2002) began a long series of excavations performed with scientific methods; about 3,000 specimens (most belonging to Ursus spelaeus) were gathered.

Besides the Ursus fossils, the macrofauna association is composed of: Crocuta spelaea, Canis lupus and Capra ibex. The microfauna assemblage is composed of: Glis glis, Microtus arvalis, Microtus agrestis, Microtus oeconomus, Chionomys nivalis, Dinaromys bogdanovi, Terricola sp., Sorex minutus, Myotis blythi, Myotis sp., Miniopterus schreibersi, and Rhinolophus sp.

Paleontological excavations have been performed in the small areas inside the "sala terminale," located about 150 $m$ from the entrance, along the western wall, called sector $A$ and another, called sector $B$ on the eastern side (Fig. 1B).

\section{Stratigraphy of Sector A}

Sector $A$ is an area of about $12 \mathrm{~m}^{2}$, divided in squares, where the team started working in 2001 and continues until now. Each 1-meter-grid square, is designated by at least one letter followed by a number (AA1, AA2, AA3, A1, A2, A3, $\mathrm{B} 1, \mathrm{~B} 2, \mathrm{~B} 3, \mathrm{C} 1, \mathrm{C} 2, \mathrm{C} 3)$. At the conclusion of the last excavation, a depth of $2.8 \mathrm{~m}$ had been reached, using the cave floor as the datum mark on the wall of the cave as zero level (Fig. 1C).

From trampling surface these levels have been identified as:

Level 0: It is the uppermost level, principally composed of landslide material coming from the collapse of the above wall, with calcareous blocks of variable dimensions, up to $1 \mathrm{~m}^{2}$. Among the clasts the matrix is composed of dark clay. This level reaches a maximum depth of $90 \mathrm{~cm}$; a few bones, including ibex, a very important vertebrate for paleoenvironmental interpretations, were found.

Level 1: This level is composed of slightly laminated, clayey silt. The layers alternate between yellow, silty sheets with a maximum thickness of $1 \mathrm{~mm}$, probably formed during periods of slightly fast-moving water through the cave system, and other sheets, black in colour. The dark layers probably are an accumulation of organic material, that perhaps settled out of especially calm waters. Sand lenses, with clasts of 2-3 mm in size, have also been observed. The thickness of level 1 reaches $40 \mathrm{~cm}$ and is paleontologically barren.

Level 1B is characterized by layers of laminated, clayey silt among numerous, large rock blocks, some with a volume of up to $250 \mathrm{dm}^{3}$, and other smaller clasts. This level can be interpreted like level 1, but the sheets of clayey silt have been deformed by the rock blocks. The thickness of this level is about $40 \mathrm{~cm}$, and this level is very poor in fossils.

Level 2 is composed of especially angular clasts of various sizes. The matrix is of dark clay. Clasts are placed in a sub-horizontal disposition, forming the evident surfaces. At present, three, main paleosurfaces are identified; the surfaces are characterized by clasts and bones, also placed in a sub-horizontal position, and by an increased presence of sandy and clayey components. The matrix shows a blackish coloration from the accumulation of organic material, which is the consequence of animal decomposition. In alternation to these surfaces, there are lenses of laminated, clayey silt with maximum bed thickness of $1 \mathrm{~mm}$. This level is the richest in fossils. On the three paleosurfaces abundant limb bones, a large fragment of a skull belonging to $U$. spelaeus, and one metatarsal of a wolf, were found (Zorzin and Bona, 2002). 

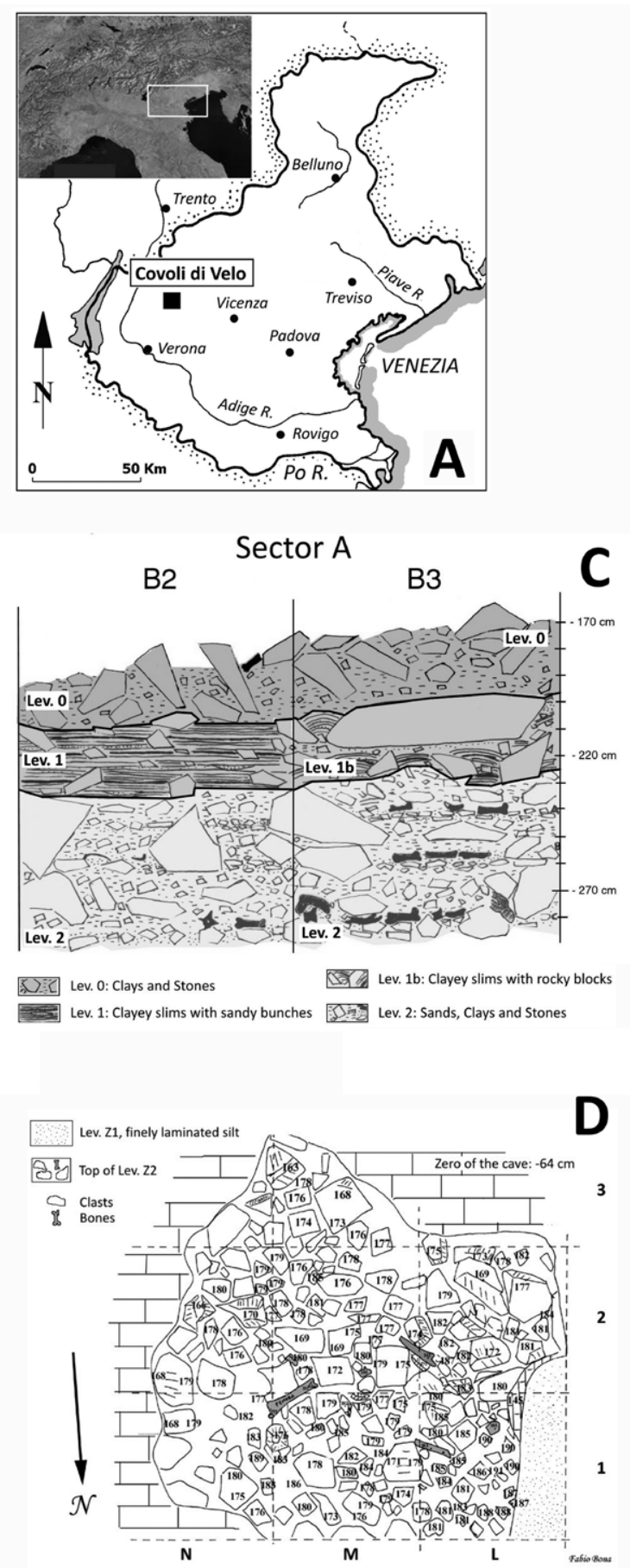

\section{COVOLI DI VELO 44-V-VR}

G.A.M. - Gruppo Amici della Montagna

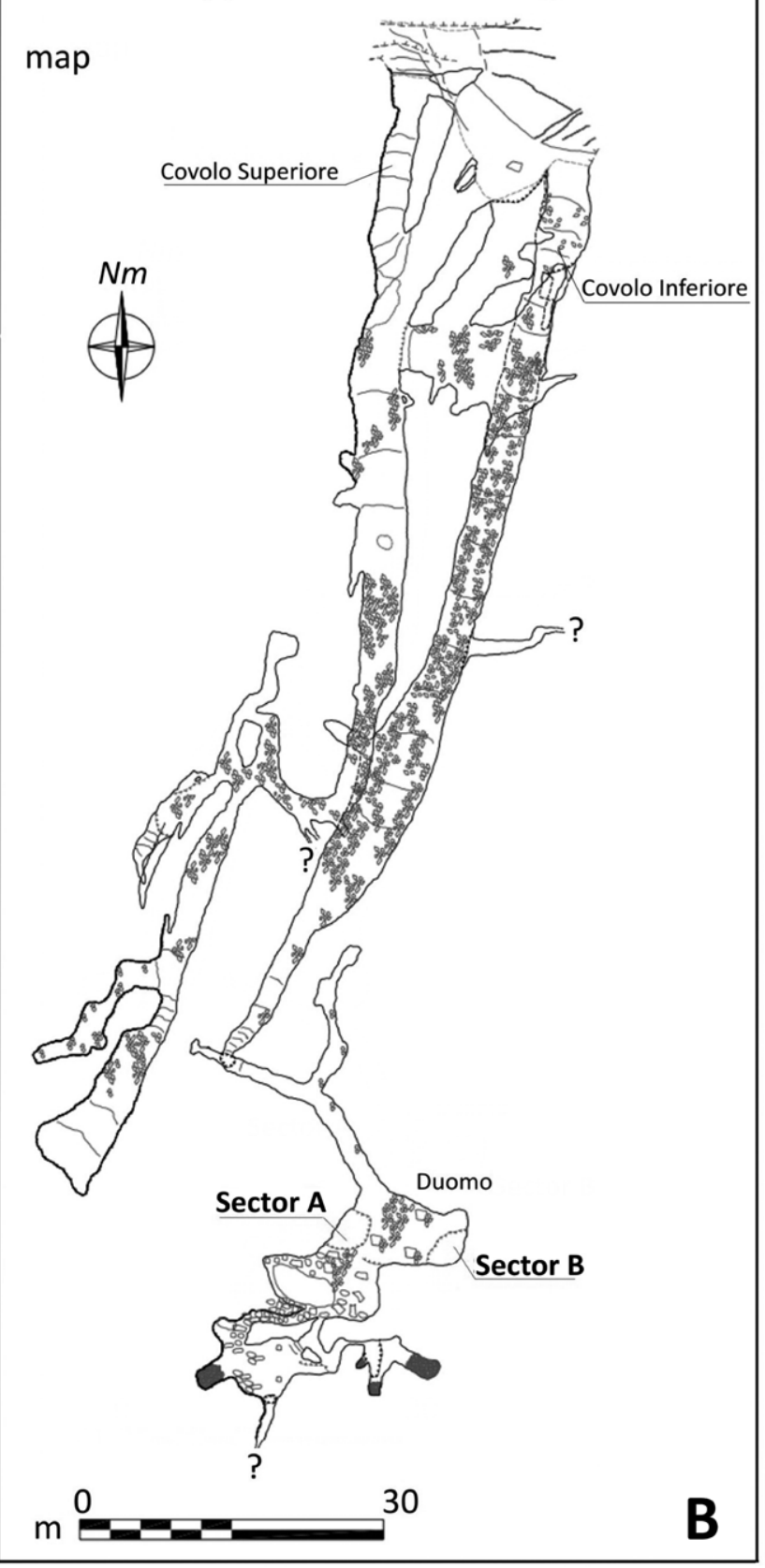

Figure 1. A - Geographical location of the Covoli di Velo Cave (Verona, Veneto region). B - Map view of the Covoli di Velo Cave showing the location of sectors A and B. C - Vertical section of portion of B2 and B3 grids in sector A (drawing F. Bona). D - Map view of the sector B showing some level Z1 sediment, and the distribution of bones and clasts in the Z2 (drawing F. Bona).

\section{Stratigraphy of Sector B}

Beginning in 2002, excavations concentrated in sector $B$ on a surface of about $9 \mathrm{~m}^{2}$. Each $1 \mathrm{~m}^{2}$ grid is designated by letters and numbers (L1, L2, L3, M1, M2, M3, N1, N2, N3). The depth of the excavation has been $1.8 \mathrm{~m}$ (October 2008) from the cave floor, located $1 \mathrm{~m}$ below the datum mark (Fig. 1D).

At present there are two stratigraphic levels:

Level Z1: This level is composed of a finely laminated, clayey silt with $1 \mathrm{~mm}$ thick beds, alternating with black beds. The yellow layers are mainly composed of silt and probably formed by the accumulation of fine material, carried by water and deposited in relatively calm waters. Alternating with those beds are black layers, formed by the deposition of 
organic material, perhaps deposited from remarkably calm waters. Some gravel and sand lenses are also found. The level $Z 1$ is $90 \mathrm{~cm}$ thick. Bone fossils are absent.

Level Z2: Five distinct layers (paleosurfaces), formed by poorly sorted and angular clasts and bones, sub-horizontally deposited, have been identified (Fig. 2). The matrix is clayey in composition and brown in color due to accumulation of organic substances. Included within the paleosurfaces are some lenses of clayey silt with laminae of 1 mm maximum thickness. All paleosurfaces of level Z2 are rich in $U$. spelaeus bones, some of which are large in size; among them, some almost complete skulls have been found. Furthermore, some bones of ibex and a femur of a wolf have also been collected (Zorzin et al., 2005).

The clear, stratigraphic similarity between the levels 1 and 2 of sector $A$ and levels $Z 1$ and $Z 2$ of sector $B$, allows us to hypothesize a depositional uniformity in the levels of two excavation areas. It is still not clear if the paleosurfaces of levels 2 and Z2 can be considered as distinct, separate levels, or if they are different areas of a single level. This question can be solved only by future excavations.

In December 2004, sediment samples from different levels of sector B were collected to search for micromammals (Bona et al., 2006) and three cores were collected to extract pollen. From these studies Bona et al. (2006) preliminarily concluded that at least two analysed pollen samples (lev. Z2 sup. 3 and lev. Z2 sup. 5) indicated an age attributable to about 18,000 years ${ }^{14} \mathrm{C}$.

\section{Material and Methods}

The Curt Engelhorn-Centre for Archaeometry (CEZA) received a bone sample (cave bear, first phalanx from L1/Z2 sup.) to determine the age by ${ }^{14} \mathrm{C}$ with the MICADAS Accelerator at their subsidiary institute, Klaus-Tschira-Archaeometry Center. Collagen was extracted from the bone and the fraction $>30 \mathrm{kD}$ separated by ultrafiltration. This fraction was freeze-dried and combusted. The $\mathrm{CO}_{2}$ was catalytically reduced to graphite.

The radiocarbon data is shown in Table 1 . The ${ }^{14} \mathrm{C}$ age is normalized to $\delta^{13} \mathrm{C}=-25 \%$ (Stuiver and Pollach, 1977). The $\delta^{13} \mathrm{C}$ value comes from the measurement of the isotope ratios in the accelerator; its error is approximately $2-3 \%$. The value can be different than the true value of the sample material because of isotope separation during sample preparation, and in the ion source of the accelerator. So, the value is only used to correct the fractionation effects. The value is, therefore, not comparable with the measurement in a mass spectrometer for stable isotopes (IRMS) and is not used for further data interpretation.

The C:N ratio and carbon content of the collagen extracted are comparable to modern bones, and the collagen preservation of the sample is good.

Radiocarbon data is, by default, reported as conventional ${ }^{14} \mathrm{C}$ age yr BP. This should not be taken as a calendar age. The origin of this convention lies in the fact that, originally, the ${ }^{14} \mathrm{C}$ data was converted to an age by using the radioactive decay equation, the radiocarbon half-life and the assumption that the atmospheric ${ }^{14} \mathrm{C}$ content is constant over time. Unfortunately, it turned out that the atmospheric content is not constant. Radiocarbon is produced in the atmosphere by interaction of neutrons with nitrogen, while neutrons are produced by galactic, cosmic rays entering the atmosphere. ${ }^{14} \mathrm{C}$ production rates vary due to changes of cosmic ray influx, which is driven by solar and terrestrial magnetic varia-

$\mathbf{L}$

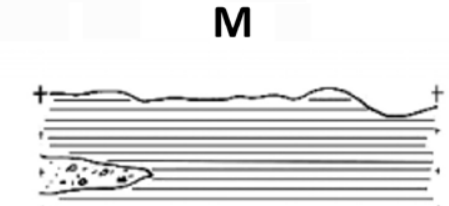

Lev. $\mathbf{Z 1}$

Lev. $\mathbf{Z 2}$

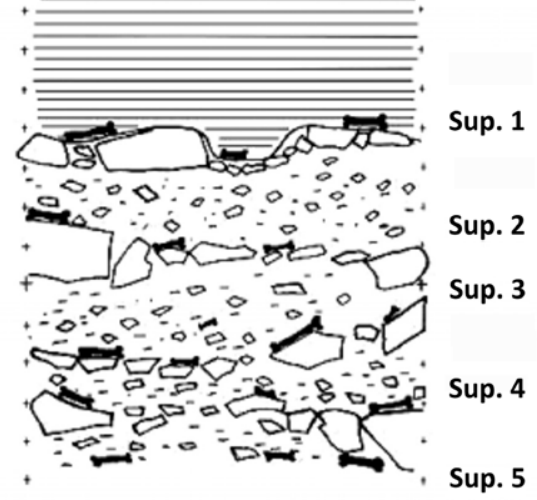

$\mathbf{N}$

Microtus arvalis, Microtus agrestis, Glis glis Terricola sp., Sorex minutus

Ursus spelaeus, Capra ibex

Ursus spelaeus, Capra ibex, Microtus agrestis, Chionomys nivalis, Dinaronys bogdanovi Ursus spelaeus, Capra ibex, Canis lupus, Microtus arvalis, Dinaromys bogdanovi

Ursus spelaeus, Chionomys nivalis

Ursus spelaeus, Microtus arvalis, Microtus agrestis, Chionomys nivalis, Dinaromys bogdanovi, Microtus oeconomus
Figure 2. Vertical section of sector $B$ with the list of the species found in stratigraphic sequence (drawing M. Accordini and F. Bona). 
Table 1. Dating of the phalanx $I^{\circ}$ from Covoli di Velo Cave (Verona, Veneto, North Italy).

\begin{tabular}{|c|c|c|c|c|c|c|c|c|}
\hline $\begin{array}{l}\text { Labor } \\
\text { No. } \\
\text { MAMS }\end{array}$ & Site & $\mathrm{C}^{14}$ (yr BP) & $13 \mathrm{C}(\%)$ & Cal 1 sigma & Cal 2 sigma & $C: N$ & C (\%) & $\begin{array}{c}\text { Collagen } \\
(\%)\end{array}$ \\
\hline 24061 & Covoli di Velo & $\begin{array}{c}29,130 \pm \\
90\end{array}$ & -15.6 & $\begin{array}{c}\text { cal } \mathrm{BC} 32,110 \\
-31,461\end{array}$ & $\begin{array}{c}\text { cal } \mathrm{BC} 32,518- \\
31,382\end{array}$ & 3.3 & 37.4 & 10.7 \\
\hline
\end{tabular}

tions and other sources (Damon et al., 1978). To cope with this, a calibration curve was established using several other methods, such as dendrochronology (until approximately 10,000 BC), Uranium-Thorium dating of speleothems and corals, and varve counting, to name a few. The chronologic limitations of radiocarbon dating are due to the half-life of ${ }^{14} \mathrm{C}$, which is $5,730 \pm 0.40$ years. After 10 half-lives, usually, most of the isotopes are decayed, therefore no material older than 50,000 years can be dated reliably with this method (Reimer et al., 2013; Olsson, 2009).

Calibrated ages are usually quoted with a 1-sigma error range, corresponding to a confidence probability of $68.3 \%$. It rises to $95.5 \%$ for 2-sigma. The calibration here was performed using the program SWISSCAL 1.0 (L. Wacker, ETH Zurich) with the INTCAL13 dataset.

\section{Discussion and Conclusion}

The results of the ${ }^{14} \mathrm{C}$ dating performed on the first phalanx of the Ursus spelaeus (I.G.VR 63925) $(29,130 \pm 0.90 \mathrm{yr}$ $\mathrm{BP}$ ), combined with pollen and faunal content preserved in the sector B of the cave (Figs. 1C-2), indicates an age of about 10,000 years older than initial estimates (Bona et al., 2006, Table 2). Using pollen data from levels Z2 surfaces $3-5$, an indirect date of 18,000 yr BP had been proposed (Bona et al., 2006). These associations suggest the presence of two geological intervals (level Z2 and Z1), corresponding to two different climatic phases. In particular, inside level Z2 (the lower one), the presence of Capra ibex, Chyonomis nivalis, Dynaromis bogdanovi, Microtus eoconomus, Microtus arvalis and Microtus agrestis suggests a cool climate and a landscape characterized by poor forest cover with open spaces. The pollen data from the surfaces 3 and 5 of this level (Bona et al., 2006, Table. 2) confirms this reconstruction. In the level Z1, the disappearance of the Capra ibex, Chionomys nivalis, Dinaromys bogdanovi and Microtus oeconomus, and the appearance of the Glis glis confirms an increase in forest cover, even if it is characterized by the presence, on its margins or inside it, of open space as indicated by the presence of Microtus arvalis and Microtus agrestis and the appearance of Terricola sp. and Sorex minutus. During this phase the climate was more humid and warm, as the pollen data also indicates (Bona et al., 2006).

The new date derived from the phalanx of $U$. spelaeus of the level $Z 2$ surface 1 pushes back earlier age estimates by about $10,000 \mathrm{yr}$. This new date coincides perfectly with the climatic conditions during the advance of the ALGM (AI-

Table 2. Several radiometric datings of Italian cave bears.

\begin{tabular}{|c|c|c|c|c|}
\hline \# & SITE & Region & $\begin{array}{c}\text { Radiometric dating } \\
\text { k yr BP }\end{array}$ & Source \\
\hline 1 & Conturines & Trentino Alto-Adige & $87 \pm 0.5$ to $108+8 /-7(230 \mathrm{Th} / \mathrm{U})$ & Withalm (1995) \\
\hline 2 & Conturines & Trentino Alto-Adige & $\begin{array}{c}107.2-115.8 \text { to } 41.9-47.5 \text { (Uran } \\
\text { series) }\end{array}$ & Rabeder et al. (1994) \\
\hline 3 & Conturines & Trentino Alto-Adige & $40.19 \pm 0,9$ & Döppes et al. (2018) \\
\hline 4 & Conturines & Trentino Alto-Adige & $>49$ & Döppes et al. (2018) \\
\hline 5 & Conturines & Trentino Alto Adige & $>50.579$ to $>46.435$ & Spöttl et al. (2018) \\
\hline 6 & Grotta Generosa & Lombardy & $38.2 \pm 1.4$ & $\begin{array}{l}\text { Bianchi-Demicheli and Oppizzi } \\
\text { (2001) }\end{array}$ \\
\hline 7 & Grotta Generosa (Level 2) & Lombardy & $39.2 \pm 1$ to $51.2 \pm 4$ & Bona (2004) \\
\hline 8 & Grotta Generosa (Level 4) & Lombardy & $46.7 \pm 2.4$ & Bona (2004) \\
\hline 9 & Grotta Generosa (Level 6) & Lombardy & $47.8 \pm 2.6$ to $50.8 \pm 5$ & Bona (2004) \\
\hline 10 & Fontana Marella (FM1) & Lombardy & $21.81 \pm 0.2$ & Perego et al. (2001) \\
\hline 11 & Fontana Marella (FM2) & Lombardy & $22.31 \pm 0.2$ & Perego et al. (2001) \\
\hline 12 & Buse di Bernardo & Trentino Alto-Adige & $25.78 \pm 0.2$ to $25.1 \pm 0.2$ & Avanzini et al. (2000) \\
\hline 13 & Paina & Veneto & $19.686 \pm 54$ & Terlato et al. (2018) \\
\hline 14 & Trene & Veneto & $19.948 \pm 55$ & Terlato et al. (2018) \\
\hline 15 & Chiostraccio Cave & Tuscany & $24.030 \pm 0.1$ & Martini et al. (2014) \\
\hline
\end{tabular}


pine Last Glacial Maximum) before a temperate-humid phase, indicated by the travertine deposits of the Sarca Valley, dated between $28,600 \pm 0.300 \mathrm{yr} \mathrm{BP}$ and $33,200 \pm 0.550 \mathrm{yr}$ BP with AMS ${ }^{14} \mathrm{C}$ dating (R.J. Van de Graaf Laboratorium of Utrecht University) (Avanzini et al., 2000). The date of 29,130 $\pm 0.90 \mathrm{yr}$ BP for the U. spelaeus population of the Covoli di Velo Cave is especially interesting, being close to the estimated time of extinction for cave bears about $24,000{ }^{14} \mathrm{C}$ yr ago (Pacher and Stuart, 2008), although a more recent paper has estimated a slightly younger period (20,930 \pm 0.140 ${ }^{14} \mathrm{C}$ yr ago) (Baca et al., 2016). Given dates on bears from other caves in Italy (Table 2), the Covoli di Velo cave bear is probably from one of the last populations living in Italy (a specimen found in the Chiostraccio cave, Siena, Tuscany, dated at $24,030 \pm 0.100{ }^{14} \mathrm{C}$ yr BP $(29,200-28,550 \mathrm{cal}$ yr BP) is the youngest cave bear in Italy (Martini et al., 2014). It is coeval with the Gamssulzen population (U. ingressus) (Austria) $(38,000-25,400 \mathrm{yr}$ BP) (Rabeder, 1999), a population often utilized for comparison in evolutionary studies. Recently Terlato et al. (2018) produced two new chronological data for Paina and Trene localities (Berici Hills, Veneto region) of 19,686 \pm 54 and 19,948 \pm 55 respectively and actually considered the youngest cave bear in Italy.

Recently Rabeder (pers. com.) suggested that the Covoli di Velo population belongs to the $U$. ingressus species which inhabited mostly Eastern Europe, having been found in Romania, Slovenia, Ukraine, Czech Republic, Slovakia and Greece, but also found in Switzerland, Austria and Germany.

However, although several morphometric studies (i.e. Stoppini et al., 2007; Santi and Rossi, 2008; Rossi and Santi, 2013) indicated a very similar size range in both populations (the Covoli and Gamssulzen), the Covoli di Velo bears have very simple features in the dentition. The Gamssulzen population and other of $U$. ingressus have derived upper fourth premolars compared to other cave bears (Rabeder et al., 2004). The Covoli di Velo population retains simple premolars, and is, consequently, particularly different from $U$. ingressus. The Covoli di Velo population shows strong similarity to $U$. spelaeus, which is more widely distributed in the western-central Europe regions (Rabeder et al., 2009), unlike $U$. ingressus (Rabeder et al., 2004).

The conclusion is that cave bears in the Italian Alps were evolutionarily conservative with large size and retention of simple dental morphologies. It is possible that a small number of bear populations with more-derived denture, for example the Basura cave population (Liguria region) (Quiles, 2004), migrated from the western Alps region, and/or members of a population from the eastern regions of the Europe, could have migrated into Italy. Rabeder (1995) and Withalm (2014) have hypothesized that the more-derived populations appeared in the eastern regions of Europe and later moved to the west through alpine areas, creating the mix of archaic and modern features that characterized cave bear populations at the end of the Pleistocene. However, the lack of more-derived populations in the eastern Alps might be because the more-derived cave bears migrated to the south toward Greece, as indicated by the presence of $U$. ingressus in the Loutrá Aridéa (Macedonia) (Tsoukala et al., 2006). To test all the hypotheses of evolution and migration, more morphological and genetic data from confidently-dated cave bear populations are necessary.

\section{Acknowledgements}

The authors thank the Soprintendenza Archeologia del Veneto, Nucleo Operativo di Verona that has granted permission for the removal of a sample of bone to the dating ${ }^{14} \mathrm{C}$, and, in particular, to Dr. Gianni De Zuccato, official archaeologist, who attended the sampling operations. We thank Dr. Greg McDonald, associate Editor of the Journal of Cave and Karst Studies and three anonymous reviewers for their useful comments. Dr. Nicoletta Benedetta Carlo-Stella (Cleveland) and Dr. Greg Mc Donald are also thanked for help with the English.

\section{References}

Avanzini, M., Bertolini, M., Betti, G., Borsato, A., Calmieri, G., Dellantonio, E., Lazinger, M., and Zambotto, P., 2000, Resti di Ursus spelaeus dalle "Buse di Bernardo" e dal "Covelo di Rio Malo" (Trentino-Italia): alcune implicazioni paleoambientali: Studi Trentini di Scienze Naturali - Acta Geologica-, v. 75(1998), p. 155-160.

Baca, M., Popović, D., Stefaniak, K., Marciszak, A., Urbanowski, M., Nadachowski, A., and Mackiewicz, P., 2016, Retreat and extinction of the Late Pleistocene cave bear (Ursus spelaeus sensu lato):. The Science of Nature, v. 103, no. 92, p. 1-17. https://doi.org/10.1007/s00114-0161414-8.

Baca, M., Nadachowski, A., Lipecki, G., Mackiewicz, P., Marciszak, A., Popovic, D., Socha, P., Stefaniak, K., and Wojtal, P., 2017, Impact of climatic changes in the late Pleistocene on migrations and extinctions of mammals in Europe: four case studies: Geological Quarterly, v. 61, no 2, p. 291-304. http://dx.doi.org/10.7306/gq.1319.

Baryshnikov, G.F., and Puzachenko, A.Yu., 2011, Craniometrical variability in the cave bears (Carnivora, Ursidae): multivariate analysis: Quaternary International, v. 245, no 2, p. 350-368. https://doi.org/10.1016/j.quaint.2011.02.035.

Baryshnikov, G.F., and Puzachenko, A.Yu., 2017, Morphometric analysis of metacarpal and metatarsal bones of cave bears (Carnivora, Ursidae): Fossil Imprint, v. 73, no 1-2, p. 7-47, https://doi.org/10.1515/if-2017-0001.

Benetti, A., 1973, La distruzione dei depositi quaternari dei “Covoli di Velo” nei Monti Lessini Veronesi: Natura Alpina, v. 24 , no. 1, p. $27-37$.

Benetti, A., and Cristoferi, W., 1968, La grotta del "Monte Gaole" e i “ Covoli di Velo" nei Lessini Veronesi: Studi Trentini di Scienze Naturali, B, v. 45 , p. $270-283$.

Benetti, A., and Sauro, F., 1999, Storia delle ricerche sul complesso carsico dei Covoli di Velo. Atti della Tavola Rotonda: "Un importante sistema carsico dei Monti Lessini: i Covoli di Velo": Verona-Camposilvano, 16-17 aprile 1999, Tipolitografia "La Grafica" Vago di Lavagno (VR), p. $5-12$. 
Bianchi-Demicheli, F., and Oppizzi, N., 2001, Ricerche speleologiche e paleontologiche nella regione del Monte Generoso: la Caverna Generosa: Bolletino della Società Ticinese di Scienze Naturali, v. 89, p. 61-66.

Bon, M., Piccoli, G., and Sala, B., 1991, I giacimenti quaternari di vertebrati fossili nell'Italia nord-orientale: Memorie Scienze Geologiche Padova, v. 43, p. 185-231.

Bona, F., Zorzin, R., Accordini, M., Mazzi, R., Gatto, R., Accorsi, C.A., Bandini Mazzanti, M., Bosi, G., Trevisan, G., and Torri, P., 2006, First paleo-environmental considerations on the Pleistocene deposits of the lower cave of Covoli di Velo (VR-Italy): Scientific Annals. School of Geology Aristotle University of Thessaloniki (AUTH), Spec. Vol. 98, p. 229-239.

Catullo, T.A., 1844, Su le caverne delle Province venete: Atti dell'I. R. Veneto Istituto, Venezia.

Cvetković, N.J., and Dimitrijević, V.M., 2014, Cave bears (Carnivora, Ursidae) from the Middle and Late Pleistocene of Serbia: A revision: Quaternary International, v. 339-340, p. 197-208. https://doi.org/10.1016/j.quaint.2013.10.045.

Damon, P.E, Lerman, J.C. and Long, A., 1978, Temporal fluctuations of atmospheric ${ }^{14} \mathrm{C}$ : casual factors and implications: Annual Review of Earth and Planetary Sciences, v. 6, p. 457-494. https://doi.org/10.1146/annurev.ea.06.050178.002325.

De Carlis, A., Alluvione, E., Fonte, A., Rossi, M., \& Santi, G., 2005, Morphometry of the Ursus spelaeus remains from Valstrona (Northern Italy): GeoAlp, v. 2, p. 115-126.

Döppes, D., Pacher, M., Rabeder, G., Lindauer, S., Friedrich, R., Kromer, B., and Rosendahl, W., 2016, Unexpected! New AMS dating from Austrian cave bear sites: Cranium, v. 33, no 1, p. 26-30.

Döppes, D., Rabeder, G., Frischauf, C., Kavcik-Graumann, N., Kromer, B., Lindauer, S., Friedrich, R., and Rosendahl, W., 2018, Extinction pattern of Alpine cave bears-new data and climatological interpretation. Historical Biology, https://doi.org/10.1080/08912963.2018.1487422.

Fabiani, R., 1919, I Mammiferi quaternari della regione veneta: Memorie Istituto di Geologia dell'Università di Padova, v. 5, p. 1-174.

Fortes, G.G., Grandal-d'Anglade, A., Kolbe, B., Fernandes, D., Meleg, I.N., Vázquez, A.G., Pinto-Llona, A.C., Constantin, S., de Torres, T.R., Ortiz, J.E., Frischauf, C., Rabeder, G., Hofreiter, M., and Barlow, A., 2017, Insights into bear behaviour from aDNA data: Aragonit, v. 22, no 1, p. 11.

Fortis, A., 1786, Extrait d'une lettre de M. l'abbé Fortis datée de Vérone le 24 Septembre 1785 à M. le Comte de Cassini de l'Académie des Sciences sur différentes pétrifications: Journal Physique, v. 28, no 1, p. 161-168.

Frischauf, C., 2014, The Cave Bear Incisors from Križna jama (Slovenia): Mitteilungen der Kommission für Quartärforschung der Österreichischen Akademie der Wissenschaften, v. 21, p. 75-83.

Grandal d'Anglade, A., and López-González, F., 2004, A study of the evolution of the Pleistocene cave bear by a morphometric analysis of the lower carnassial: Oryctos, v. 5, p. 83-94.

Gretzinger, J., Reiter, E., Urban, C., Bocherens, H., Sabol, M., Schuenemann, V., and Krause, J., 2017, Genetic analysis of a cave bear-morphothype specimen from Prepoštská cave, Slovakia featuring carnivorous-like isotopic signature: Aragonit, v. 22, no 1, p. 11-12.

Hofreiter, M., Capelli, C., Krings, M., Waits, L., Conard, N., Münzel, S., Rabeder, G. Nagel, D., Paunovic, M., Jambrěsić, G., Meyer, S., Weiss, G., and Pääbo, S., 2002, Molecular Biology and Evolution, v. 19, no 8, p. 1244-1250. https://doi.org/10.1093/oxfordjournals.molbev.a004185.

Martini, I., Coltorti, M., Mazza, P.P.A., Rustioni, M., and Sandrelli, F., 2014, The latest Ursus spelaeus in Italy, a new contribution to the extinction chronology of the cave bear: Quaternary Research, v. 81, p. 117-124. http://doi.org/10.1016/j.yqres.2013.10.003.

Massalongo, O., 1851, Osteologia degli Orsi fossili nel Veronese, con un saggio sopra le principali caverne del Distretto di Tregnago: Naturwissenschaftliche Abhandlungen, v. 4, p. 1-110.

Olsson, I.U., 2009, Radiocarbon dating history: early days, questions, and problems met. Radiocarbon, v. 51, p. 1-43. https://doi.org/10.1017/ S0033822200033695.

Omboni, G., 1875, Di alcuni oggetti preistorici delle caverne di Velo Veronese: Atti della Società Italiana di Scienze Naturali e del Museo Civico di Storia Naturale di Milano, v. 18, p. 69-82.

Orlando, L., Bonjean, D., Bocherens, H., Thenot, A., Argant, A., Otte, M., and Hänni, C., 2002, Ancient DNA and the population genetics of cave bears (Ursus spelaeus) through space and time: Molecular Biology and Evolution, v. 19, no 11, p. 1920-1933. https://doi.org/10.1093/oxfordjournals.molbev.a004016.

Pacher, M., and Stuart, A.J., 2008, Extinction chronology and paleobiology of the cave bears (Ursus spelaeus): Boreas, v. 38, p. 189-206. https://doi.org/10.1111/j.1502-3885.2008.00071.x.

Perego, R., Zanalda, C., and Tintori, A., 2001, Ursus spelaeus from Grotta Sopra Fontana Marella, Campo dei Fiori Massif (Varese, Italy) : morphometry and paleoecology : Rivista Italiana di Paleontologia e Stratigrafia, v. 197, no 3, p. 451-462.

Plichta, A., Rablíčkova, M., and Káňa, V., 2017, Morphometrical analyses of cave bear populations from Barová cave in moravian karst (Czech Republic): Aragonit, v. 22, no 1, p. 20-21.

Quiles, J., 2004, Analyse morphodynamique de l'ours des caverne (Carnivora, Ursidae) de cinq sites du pourtour Méditerranéen : Cahiers scientifique du Muséum d'Histoire naturelle de Lyon Hors Série, v. 2, p. 149-161.

Rabeder, G., 1995, Evolutionsniveau und Chronologie der Höhlenbären aus der Gamssulzen-Höhle im Toten Gebirge (Oberösterreich). Mitteilungen der Kommission für Quartärforschung der Österreichischen Akademie der Wissenschaften, Band 9, p. 69-81.

Rabeder, G., 1999, Die Evolution des Höhlenbärengebisses. Mitteilungen der Kommission für Quartärforschung der Österreichischen Akademie der Wissenschaften, Band 11, p. 1-102.

Rabeder, G., 2014, Metrics and Evolutionary Level of Teeth of the Bears from Križna jama (Slovenia): Mitteilungen der Kommission für Quartärforschung der Österreichischen Akademie der Wissenschaften, v. 21, p. 57-63.

Rabeder, G., Steffan, I., and Wild, E., 1994, The chronological position of the cave bears from Conturines cave: Abstract, $2^{\text {nd }}$ International Cave Bears Symposium Alta Badia.

Rabeder, G., Frischauf, C., and Nielsen, E., 2017, Steigelfadbalm, eine fossilführende Bärenhöhle in der Nagelfluh der Rigibei Luzern (Zentralschweiz): Die Höhle, v. 68, no 1-4, p. 124-133.

Rabeder, G., Hofreiter, M., Nagel, D., and Withalm, G., 2004, New taxa of alpine cave bears (Ursidae, Carnivora): Cahiers scientifique du Muséum d'Histoire naturelle de Lyon Hors Série, v. 2, p. 49-68.

Reimer, P.J., Baillie, M.G.L., Bard. E., et al., 2013, IntCal09 and Marine09 radiocarbon age calibration curves, 0-50,000 years cal BP: Radiocarbon, v. 51, p. 1111-1150. https://doi.org/10.1017/S0033822200034202.

Robu, M., 2016, Age re-assessment of the cave bear assemblage from Urşilor Cave, north-western Romania: International Journal of Speleology, v. 45, no. 2, p. 123-133. http://doi.org/10.5038/1827-806X.45.2.1947.

Rosenmüller, J.CH., 1794, Quaedam de ossibus fossilibus animalis cujusdam, historiam ejus et cognitionem accuratiorem illustrantia, dissertatio, quam d. 22.October 1794. ad disputandum proposuit loannes Christ : Rosenmüller Heßberga-Francus, LL. AA. M. in Theatro anatomico 
Lipsiensi Prosector assumto socio lo. Chr. Aug. Heinroth Lips. Med. Stud. Cum tabula aenea.- Leipzig.

Rossi, M., and Santi, G., 2013, Studio morfometrico e morfodinamico di resti craniali, dentali e mandibolari di Ursus spelaeus dalla Grotta del Buco del Frate e dall'Altopiano di Cariadeghe (Brescia) nel quadro evolutivo degli orsi delle caverne: Natura Bresciana, Annali del Museo Civico di Storia Naturale Brescia, v. 38, p. 33-43.

Sabol, M., 2005, Cave Bears (Ursidae, Mammalia) from the Trojuholník Cave (Slovakia): Mitteilungen der Kommission für Quartärforschung der Österreichischen Akademie der Wissenschaften, v. 14, p. 161-175.

Santi, G., and Rossi, M., 2001, Bears from the Buco dell'Orso Cave (Laglio-Como, Lombardy-Northern Italy). I : Morphometric study of the cranial and mandibular fossil remains: Atti Ticinensi di Scienze della Terra, Pavia, v. 42, p. 75-100.

Santi, G., and Rossi, M., 2008, Fossili craniali e mandibolari di Ursus da grotte del Veneto (Italia Settentrionale) nuove osservazioni sul quadro evolutivo degli orsi italiani: Atti del Museo Civico di Storia Naturale di Trieste, suppl. al v. 53, p. 3-12.

Santi, G., and Rossi, M., 2014, Metapodial bones of Ursus gr. spelaeus from selected caves of the North Italy. A biometrical study and evolutionary trend. Annales de Paléontologie, v. 100, p. 237-256. https://doi.org/10.1016/j.annpal.2014.01.003.

Santi, G., Rossi, M., and Pomodoro, S., 2003, Ursus spelaeus Rosenmüller-Heinroth, 1974 remains from Buco dell'Orso Cave (Laglio, Como, Lombardy-Northern Italy-). III - Metapodial bones: morphometric analysis: Bulletin de l'Institut Royal des Sciences Naturelles de Belgique, v. 73, p. 195-219.

Santi, G., Rossi, M., and Dellantonio, E., 2011, Ursus spelaeus Rosenmüller, 1794 from the "Buse di Bernardo" (Tesero, Trento Province, Northern Italy): morphometric, morphodynamic and evolutionary frame. Revue de Paléobiologie Genève, v. 30, no. 1, p. $223-249$.

Spötl, C., Reimer, P.J., Rabeder, G., and Scholz, D., 2014, Presence of cave bears in western Austria before the onset of the Last Glacial Maximum: new radiocarbon dates and palaeoclimatic considerations: Journal of Quaternary Science, v. 29, no 8, p. 760-766. https://doi. org/10.1002/jqs.2747.

Spötl, C., Reimer, P.J., Rabeder, G., and Bronk-Ramsey, C., 2018, Radiocarbon constraints on the age of the world's highest-elevation cave-bear population, Conturines cave (Dolomites, Northern Italy): Radiocarbon, v. 60, no 1, p. 299-307. https://doi.org/10.1017/RDC.2017.60.

Stoppini, M., Bonin, M., Gironi, B., Rossi, M., and Santi, G., 2007, Morphodynamic analysis of Ursus spelaeus dentition from caves of the Lombardia and Veneto Regions caves (North Italy): preliminary data on $\mathrm{P}^{4} / 4$ and lower carnassials $\left(\mathrm{M}_{1}\right)$ : Grzybowski Foundation Special Publication, v. 12, p. 93-103.

Stuiver, M., and Polach, H.A., 1977, Discussion: reporting of ${ }^{14} \mathrm{C}$ data: Radiocarbon, v. 19, p. 355-363. https://doi.org/10.1017/ S0033822200003672.

Terlato, G., Bocherens, H., Romandini, M., Nannini, N., Hobson, K.A. and Peresani, M., 2018, Chronological and isotopic data support a revision for the timing of cave bear extinction in the Mediterranean Europe: Historical Biology, https://doi.org/10.1080/08912963.2018.1448395.

Torres Pérez Hidalgo, T., 1988a, Osos (Mammalia, Carnivora, Ursidae) del Pleistocene Ibérico (U. deningeri Von Reichenau, U. spelaeus Rosemüller-Heinroth, U. arctos Linneo). I. Filogenia, distribution stratigrafca y geografca. Estudio anatomico y metrico del craneo. Boletín Geológico y Minero, v. 99, no 1, p. 3-46.

Torres Pérez Hidalgo, T., T. (1988b): Osos (Mammalia, Carnivora, Ursidae) del Pleistocene Ibérico (U. deningeri Von Reichenau, U. spelaeus Rosemüller-Heinroth, U. arctos Linneo). II. Estudio anatomico y metrico de la mandibula, hioides, atlas y axis: Boletín Geológico y Minero, v. 99, no 2, p. 220-249.

Torres Pérez Hidalgo, T., 1988c, Osos (Mammalia, Carnivora, Ursidae) del Pleistocene Ibérico (U. deningeri Von Reichenau, U. spelaeus Rosemüller-Heinroth, U. arctos Linneo). III. Estudio anatomico y metrico del miembro toracico, carpo y metacarpo: Boletín Geológico y Minero, v. 99, no 3, p. 356-412.

Torres Pérez Hidalgo, T., 1988d, Osos (Mammalia, Carnivora, Ursidae) del Pleistocene Ibérico (U. deningeri Von Reichenau, U. spelaeus Rosemüller-Heinroth, U. arctos Linneo). IV. Estudio anatomico y metrico del miembro pelviano, tarso, metatarso y dedos: Boletín Geológico y Minero, v. 99, no 4, p. 516-577.

Torres Pérez Hidalgo, T., 1988e, Osos (Mammalia, Carnivora, Ursidae) del Pleistocene lbérico (U. deningeri Von Reichenau, U. spelaeus Rosemüller-Heinroth, U. arctos Linneo).V. Denticion decidual, formula dentaria y denticion superior: Boletín Geológico y Minero, v. 99, no 5, p. 660-714.

Torres Pérez Hidalgo, T., 1988f, Osos (Mammalia, Carnivora, Ursidae) del Pleistocene Ibérico (U. deningeri Von Reichenau, U. spelaeus Rosemüller-Heinroth, U. arctos Linneo).VI. Denticion inferior: Boletín Geológico y Minero, v. 99, no 6, p. 886-940.

Tsoukala, E., Chatzopoulou, K., Rabeder, G., Pappa, S., Nagel, D., and Withalm, G., 2006, Paleontological and stratigraphical research in Loutrá Aridéas bear cave (Almopia Speleopark, Pella, Macedonia, Greece): Scientific Annals, School of Geology Aristotle University of Thessaloniki (AUTH), Special Vol. 98, p. 41-67.

Volta, S., 1796, Ittiolitologia Veronese, Giuliari, Verona, p. 46-48.

Withalm, G., 2011, Analysis of cave bear metapodial bones from Ajdovska jama near Krško (Slovenia): Mitteilungen der Kommission für Quartärforschung der Österreichischen Akademie der Wissenschaften, v. 20, p. 65-71.

Withalm, G., 2014, Analysis of the Cave Bear metapodial bones from Križna jama (Slovenia): Mitteilungen der Kommission für Quartäforschung der Österreichischen Akademie der Wissenschaften, Band 21, p. 117-122.

Zorzin, R., and Bona, F., 2002, Covoli di Velo (VR), Prima campagna paleontologica: risultati preliminari: Bollettino del Museo Civico di Storia Naturale di Verona, Geologia Paleontologia Preistoria, v. 26, p. 43-46.

Zorzin, R., and Rossi, G., 1999, Il sistema carsico dei Covoli di Velo. Atti Tavola Rotonda: "Un importante sistema carsico dei Monti Lessini (VR): i Covoli di Velo": Verona-Camposilvano, 16-17 aprile 1999, Tipolitografia “La Grafica” Vago di Lavagno (VR), p. 13-22.

Zorzin, R., Bona, F., and Accordini, M., 2005, From 2001 to 2004: paleontological excavations in the Grotta inferiore dei Covoli di Velo (Veneto Italy): 4th International Congress of Speleology, 21-28 August 2005, Kalamos, Hellas, Hellenic Speleological Society, O-23, p.1-8. 